\section{Source Book in Bioethics: a Documentary History}

\author{
Edited by Albert $\mathbf{R}$ Jonsen, Robert $M$ \\ Veatch and LeRoy Walters, Washing- \\ ton DC, Georgetown University \\ Press, 1998, 570 pages, $\$ 95.00$, \\ $£ 73.95$.
}

The three editors of this source book have been prominent in the field of bioethics for almost three decades. During this time there have been major developments in medicine which have created numerous ethical dilemmas, many of which have led to legal landmarks and have been the subject of public policy statements. The editors have gathered together a vast collection of legal judgments, public documents and government reports in the following fields in bioethics: experimentation on human subjects; death and terminal illness; organ transplantation; reproduction; child care; genetics, and changes in the nature of health care provision. Most of the material in this text has been previously published and the editors' intention is to provide a comprehensive source book for the student and scholar. It is quite useful to have such a wealth of material in one large volume which would be an asset to a department library.

Albert Jonsen is responsible for editing the first part, which brings together material on the ethical status of research involving human subjects. This includes the Nuremberg Code, the Declaration of Helsinki, documents and reports regarding the protection of human subjects in medical research, research undertaken on minors, in vitro fertilisation and human fetal tissue transplantation.

Robert Veatch, who edits the second part, brings together material which charts changing attitudes towards death and dying and includes selections from the President's Commission on the Definition of Death, which was originally published in 1981, and also selections from the commission's subsequent report on decisions to forego life-sustaining therapy, first published in 1993. Central to both of these reports were the legal and moral debates over Karen Quinlan, Claire Conroy and Nancy Cruzan. These cases became legal landmarks and the relevant documents are included here, together with other material from the
US courts such as the Californian Natural Death Act.

LeRoy Walters edits parts three and four, which cover ethical issues in human genetics and human reproductive technologies respectively. Ethical problems in relation to genetic screening, genetic testing and gene therapy occupy the first collection of documents in part three, and these are followed by excerpts from reports concerning the attempt to map and sequence the human genome. In the following part Walters includes reports on the ethico-legal issues arising out of the new reproductive technologies, such as choices for the infertile, problems arising out of surrogate motherhood arrangements, and the ethical and legal status of embryos and newborns.

The final section is edited by Robert Veatch and it is devoted to the emerging ethical issues in relation to changes in the health care system. In his introductory essay Veatch charts the development of the "rights" perspective in the US and the rejection of Hippocratic paternalism. Material here includes the USA's Anatomical Gift Act, reports from the US Task Force on Organ Transplantation, The President's Commission on Making Health Care Decisions, and related US court rulings on health care decision making.

With the exception of several documents in parts three and four, such as the Warnock Committee's Report on Human Fertilisation and Embryology, and the Glover Commission's Report on the Ethics of the New Reproductive Technologies, the bulk of the material in this collection relates to the American history of bioethics and consequently provides an interesting insight into the attitudes and ethical perspectives which have emerged on that continent during the past thirty or so years.

However, this is a very useful text to have at one's fingertips, especially as many of the documents, published by transient public authorities, are either hard to locate or out of print.

DAVID LAMB University of Birmingham

\section{A New Paradigm For Informed Consent}

Irene S Switankowsky, Lanham, University Press of America, 1998, xviii + 135 pages, $\$ 32.00$.
Irene Switankowsky rightly recognis $e_{\text {e. }}$ that the rhetoric of informed conse can be realised in practice only under certain conditions, conditions se thinks are currently absent. The state purpose of her book is to explore the conditions and to help in their realis tion. It seeks to do this by gatheriag together what Switankowsky takes $\varnothing$ be all the elements necessary achieving a fully informed consent. also seeks to offer practical guidanoe as to how to recognise when the conditions in question have been me्षु Does the book do what it claims? In word, no.

For this there are it seems to me two reasons. First, the book is stylisticalde ill-suited to having any practical ing pact, and second there is a tension between rhetoric and practice at $\overrightarrow{i t s}$ own core.

Stylistically, apart from the occosional discussions of cases, of whiक more below, the book consists largely of uninspiring conceptual unpackirfe Perhaps it is a failing of mine, but understanding of, for example, effect tive physician-patient communicatio is not improved by having my attee tion drawn in the abstract to concepols such as honesty, which are deemegt necessary to its realisation. I'm nA helped in such cases because I do $n \vec{B}$ so much need to be told such things to be in some sense reminded of ther And I would be better reminded of them by well-chosen illustrations than by conceptual analysis.

The tension at the core of the boods which forms the second reason why fails in its stated purpose, appears in Switankowsky's consideration of hegr case material. Switankowsky's rhetoric is clear enough. There is an insistence throughout the book that it is the values, beliefs and attitudes of the patient which should determine medio cal decisions. Deciding in accordane with these should replace deciding is accordance with paternalistic, somes times coercive, certainly manipulative physician attitudes. When these are replaced, Switankowsky says, then the "autonomy enhancing model" of cone sent will become a reality, instead of the historically dominant "harmp avoidance" model. In the former, bi not in the latter, there is genuirfs informed consent.

This is the rhetoric, but it is not realised in Switankowsky's case dise cussions. According to Switankowslo a necessary condition of informeg autonomous consent is rationality Bearing that in mind, here is one casos Switankowsky considers. 